\title{
Ecophysiology of peanuts grown under water deficit regimes
}

\section{Ecofisiologia do amendoinzeiro cultivado sob regimes de déficit hídrico}

\author{
Juliana CARBONIERI ${ }^{1}$; Getúlio Takashi NAGASHIMA²; Heverly MORAIS 2 ; Julia Pelegrineli FASOLIN³ \\ Paulo Henrique CARAMORI'2; Valdir ZUCARELI3; Moacyr Eurípedes MEDRI ${ }^{1}$
}

\begin{abstract}
1 Universidade Estadual de Londrina, Centro de Ciências Biológicas, Departamento de Biologia Animal e Vegetal, Caixa Postal 6001, CEP 86051-990 Londrina, PR. E-mail: jucarbonieri@gmail.com , moacyrmedri@uel.br

${ }^{2}$ Instituto Agronômico do Paraná - IAPAR, Departamento de Fisiologia Vegetal e Agrometeorologia, Rodovia Celso Garcia Cid, km 375, CEP 86047-902 Londrina, PR. E-mail: gtnagashima@iapar.br, heverlymorais@gmail.com , pcaramori@gmail.com

3 Universidade Estadual de Maringá - Campus Umuarama, Centro de Ciências Agrárias, CEP 87506-370, Umuarama, PR. Email: Julia_pelegrineli@hotmail.com , valdirzucareli@yahoo.com.br
\end{abstract}

Recebido em: 17-05-2018; Aceito em: 29-01-2021

\begin{abstract}
This study evaluates physiological aspects of two peanut cultivars (Arachis hypogaea L. IAPAR 25 Tição and IAC Tatu ST) grown under water regimes in order to verify drought tolerance. The randomized block experimental design was used in a $2 \times 3$ factorial design (two cultivars and three water regimes). The water regimes were, namely: control, in which plants were maintained at field capacity conditions (FC - without water deficit); moderate water deficit (MD - 50\% of water deficit); and severe water deficit (SD - 75\% of water deficit) in relation to control. Relative water content, gas exchange, dry matter, and leaf proline content were analyzed. Both cultivars developed physiological mechanisms of acclimatization to water deficit, such as reducing leaf relative water content, $\mathrm{CO}_{2}$ assimilation rate, stomatal conductance, and transpiration in the initial period of water deficit, besides increasing proline production. Such physiological changes negatively affected dry matter accumulation in the grains and the number of grains, as well as dry matter accumulation in shoots and roots.
\end{abstract}

Additional keywords: Arachis hypogaea, water stress, gas exchange.

\section{Resumo}

O objetivo desse trabalho foi estudar aspectos fisiológicos de duas cultivares de amendoinzeiro (IAPAR 25 Tição e IAC Tatu ST), cultivadas sob regimes hídricos, a fim de verificar a tolerância à seca. O delineamento experimental utilizado foi o de blocos ao acaso, em esquema fatorial $2 \times 3$ (duas cultivares e três regimes hídricos). Os regimes hídricos foram: controle, no qual as plantas foram mantidas em condições de capacidade de campo (CC - sem déficit hídrico); déficit hídrico: moderado (DM - 50\% de déficit hídrico) e severo (DS - 75\% de déficit hídrico) em relação ao controle. Foram analisados: conteúdo relativo de água, trocas gasosas, massa seca e teor de prolina nas folhas. As duas cultivares desenvolveram mecanismos fisiológicos de aclimatação ao déficit hídrico, como redução no conteúdo relativo de água nas folhas, na taxa de assimilação de $\mathrm{CO}_{2}$, na condutância estomática e na transpiração, no período inicial de déficit hídrico, além de aumento da produção de prolina. Tais alterações fisiológicas afetaram negativamente a acumulação de massa seca nos grãos e o número de grãos, assim como a acumulação de massa seca na parte aérea e nas raízes.

Palavras-chave adicionais: Arachis hypogaea, estresse hídrico, trocas gasosas.

\section{Introduction}

The peanut crop is among the most cultivated oilseeds in the world, being planted on a large scale in the American, African, and Asian continents. Planting is aimed to the production of grains, oil, and bran, among others. Environmental conditions, nutrient supply, and management must be adequate to achieve high yield for this crop. Therefore, knowledge of its ecophysiology enables to exploit its maximum yield potential (Ferrari Neto et al., 2012).

The peanut plant is not influenced by photoperiod and light is not a limiting factor at field conditions, and among other requirements, the crop water requirement reaches its maximum in the flowering and fruiting phases (Ferrari Neto et al., 2012). Soil water deficit at the beginning of development of the peanut causes problems such as germination delay and irregularities (Cato et al., 2008). In addition, it affects the physiological functions of plants, especially photosynthesis and respiration, which can alter growth, development, anatomy, and reproduction. However, under water restrictions, plants have adaptation and acclimatization mechanisms that allow their survival. Besides physiological changes to control water loss, metabolic adjustments and osmotic balances are also mechanisms that can be manifested by the plant. As an example, accumulation of solutes such as proline, mannitol, and sorbitol decrease the osmotic potential of plants through increasing intracellular solutes, which 
can assist in turgor maintenance, sustaining cell elongation and the expansion of growth regions (Carvalho, 2005; Farooq et al., 2009; Nascimento et al., 2011; Pereira et al., 2012; Taiz \& Zeiger, 2013).

So as to detect the ecophysiological mechanisms of peanuts acclimatization to low water availability, Nogueira et al. (1998) found that water deficit increased the diffusive resistance to water vapor by stomatal closure, reducing $\mathrm{CO}_{2}$ supply for both photosynthesis and transpiration. Correia \& Nogueira (2004) observed that water deficit decreased height, number of leaves, and leaf area of the peanut crop after 35 days, increasing biomass allocation to the roots. Araújo \& Ferreira (1997) observed decreases in leaf area and shoot and root dry matter caused by water deficit, and Vorassot et al. (2003) observed significant decreases in production and agronomic characteristics such as plant height and number of pods and grains in peanut plants submitted to water deficit.

Detection of differences in acclimatization mechanisms and negative responses of four cultivars (BR 1, BRS 151 L 7, Senegal, and CNPA Havana) to conditions of low water availability is of great importance for crop breeding programs, management programs, and cultivar selection (Nogueira \& Santos, 2000).

To understand the physiological mechanisms of acclimation to water deficit of the peanut crop, this study evaluates ecophysiological aspects and dry matter production in the cultivars IAC Tatu ST and IAPAR 25 Tição, which are widely used by farmers, under water deficit regimes.

\section{Material and methods}

The experiment was conducted in a greenhouse made of transparent glass, $16 \mathrm{~m}$ wide, $40 \mathrm{~m}$ long, and $6 \mathrm{~m}$ high located at the Instituto Agronômico do Paraná, IAPAR, in Londrina, Paraná state, Brazil (23ํㅜㅇ 22 ' S; $51^{\circ} 10^{\prime} \mathrm{W}$; $585 \mathrm{~m}$ altitude). The following two upright-growing, early maturity (90-110 days) peanut cultivars were evaluated: IAPAR 25 Tição and IAC Tatu ST. They were sown in pots with capacity of $20 \mathrm{~L}$, upper diameter of $19.8 \mathrm{~cm}$, lower diameter of $13.7 \mathrm{~cm}$, and height of $15.5 \mathrm{~cm}$, containing $15 \mathrm{~kg}$ of the following substrate: washed medium sand - $3 \mathrm{~kg}$, organic matter from dry, tanned, and sieved poultry litter - $3 \mathrm{~kg}$, and dystropherric Red Latosol of $0.20 \mathrm{~m}$ depth, according to classification by Santos et al. (2013) - 9 kg.

Ten seeds per pot were sown on November 17 , 2010. At 16 days after sowing (DAS), the first thinning was conducted, maintaining two plants per pot. At 20 DAS, the second thinning was conducted, maintaining one plant per pot.

The randomized block experimental design in a $2 \times 3$ factorial design was used, with the factors being two cultivars and three water regimes, totaling six treatments with 15 replicates of one pot per plot. Pots were on an $80-\mathrm{cm}$ high table.

From sowing to 20 DAS, all pots received the same water amount to provide uniform plant development. Irrigation was conducted every three or four days and volume was calculated from the water amount lost through evapotranspiration, measured by weighing five reference pots, with a total of five waterings and an average of $1140 \mathrm{~mL} /$ watering.

After this period, plants were subjected to the following three water regimes: field Capacity (FC) control plants maintained at field capacity conditions (without water deficit); moderate deficit (MD) - plants with $50 \%$ water restriction compared to the control group (water deficit of $50 \%$ water deficit); and severe deficit (SD) - plants with $75 \%$ water restriction compared to the control group (water deficit of $75 \%$ ). The gravimetric method was used as methodology to determine the three water regimes. For this, five pots of each cultivar were added to the experiment and maintained as a reference to determine the water volume needed to restore the field capacity as a function of evapotranspiration. Irrigation was conducted every three or four days and its volume was calculated from the average value of weight of the five reference pots.

The water amount supplied to the plants throughout the experiment is shown in Table 1.

Table 1 - Amount of water offered to the peanut cultivars, throughout the experiment.

\begin{tabular}{lcc}
\hline Cultivar & Water regimes & Amount of water (liter/cicle) \\
\hline IAPAR 25 Tição & Field Capacity & 55.2 \\
IAC Tatu ST & Field Capacity & 54.8 \\
IAPAR 25 Tição & Moderate deficit & 30.4 \\
IAC Tatu ST & Moderate deficit & 30.2 \\
IAPAR 25 Tição & Severe deficit & 18.0 \\
IAC Tatu ST & Severe deficit & 18.0 \\
\hline
\end{tabular}

The effect of water deficit treatments was evaluated using the following variables:

\section{Leaf relative water content}

Relative water content (RWC) was calculated based on the fresh matter (FM), turgid matter (TM), and dry matter (DM) of leaves through the following equation: $\mathrm{RWC}=[(\mathrm{MF}-\mathrm{DM}) /(\mathrm{TM}-\mathrm{DM})] \times 100$.
To calculate RWC, one leaf per plant was evaluated for each treatment, being collected in four moments to also evaluate the period of turgidity of plants. For this purpose, leaves were collected four hours after irrigation at 15 days after the beginning of treatments (DAT); one day after irrigation at 30 DAT; two days after irrigation at 60 DAT; and three days after irrigation at 75 DAT. Fully expanded leaves located in 
the median portion of the plant and branch were collected. In order to obtain turgid matter, leaves were submerged in ordinary water for 24 hours. To determine dry matter, leaves were maintained in a forced-air circulation oven at $60{ }^{\circ} \mathrm{C}$ for 96 hours. After this procedure, the leaves were removed from the oven and immediately weighed through analytical balance with resolution of $0.0001 \mathrm{~g}$.

\section{Net photosynthetic rate, stomatal conductance, and transpiration}

Net photosynthetic rate $\left(\mu \mathrm{mol} \mathrm{CO}_{2} \mathrm{~m}^{-2} \mathrm{~s}^{-1}\right)$, stomatal conductance $\left(\mathrm{mol} \mathrm{m} \mathrm{m}^{-2} \mathrm{~s}^{-1}\right)$, and transpiration $\left(\mathrm{mmol} \mathrm{m} \mathrm{m}^{-2} \mathrm{~s}^{-1}\right.$ ) were evaluated at 15,45 , and 60 days after treatments (DAT) through the IRGA device (InfraRed Gas Analyzer) (LI-COR, model LI-6200). Four plants of each treatment were randomly selected between 9 a.m. and 11 a.m., as it is the period when gas exchange is most active, because of good availability of photosynthetic radiation and mild temperature at the time and location of the experiment and evaluated. Measurements were made on young leaves, fully expanded, in a leaflet of the third or fourth leaf counted from the apex of the branch.

\section{Stomatal number and size}

The anatomical analysis of stomatal number and size was conducted at 40 DAT on two adult and fully expanded leaves in five replicates. Collection was conducted between 8 and 9 a.m. and there were no clouds at the time of collection. The median abaxial region of the right and left distal leaflets was used as standard for analysis of the epidermis. The segments were immediately fixed in FAA 70\% (formol, acetic acid, and ethyl alcohol) for 24 hours. After this period, they were subjected to the usual techniques for preparing semi-permanent slides (Macêdo, 1997). All sections were made freehand with the aid of a steel blade, stained in a solution of astra blue and basic fuchsin (Kraus \& Arduin, 1997), mounted on glycerin sheets, and subsequently sealed with colorless resin.

\section{Leaf proline content}

In order to determine proline content, two leaves from each treatment were collected at 40 DAT in five replicates. Fully expanded leaves located in the median portion of the plant and branch were collected, being placed in liquid nitrogen immediately after collection and transferred to a freezer at $-80^{\circ} \mathrm{C}$ until the time of analysis. For analyzes, $100 \mathrm{mg}$ of leaf tissue previously macerated in liquid nitrogen were used following methodology described by Bates et al. (1973). Analyzes were performed in triplicate and proline results obtained in $\mu \mathrm{mol} \mathrm{g}^{-1} \mathrm{FM}$.

All results were subjected to analysis of variance and means of cultivar and treatment were compared by Tukey test at $5 \%$ probability using the SISVAR statistical program.

\section{Dry matter of shoots, roots, and grains}

Dry matters of roots, shoots, and grains were obtained by separating and packing each of these plant parts in paper bags previously identified and deposited in a forced-air circulation oven at $60{ }^{\circ} \mathrm{C}$ for 96 hours. After being removed from the oven, plant parts were immediately weighed on an analytical balance with weighing capacity of $100 \mathrm{~g}$ and resolution of $0.01 \mathrm{mg}$. This procedure was performed on all plants at 80 days after the beginning of treatments (DAT). Based on the values obtained from weighting, the ratio between shoot and root dry matter was calculated.

\section{Results}

Treatments differed for relative water content (RWC) in the first 15 days after reduction of the water amount supplied to the plants, with the lowest values observed in the cultivar IAPAR 25 Tição under severe water deficit (SD). At 30 and 60 DAT, RCW was also lower in the most severe water deficit condition for both cultivars. At 75 DAT, difference was not observed between water treatments. Comparing cultivars, the cultivar IAPAR 25 Tição showed higher RWC than IAC Tatu ST only at 75 DAT (Table 2).

Table 2 - Relative Water Content (RWC) (\%) in leaves of Arachis hypogaea (IAPAR 25 Tição (Tição) and IAC Tatu ST (Tatu)) grown under field capacity (FC - without water deficit), moderate water deficit (MD - 50\% water deficit) and severe water deficit (SD - 75\% water deficit) at 15, 30, 60 and 75 days after treatments starts (DAT).

\begin{tabular}{lcccccccc}
\hline \multirow{2}{*}{$\begin{array}{l}\text { DAT } \\
\text { Collection after irrigation }\end{array}$} & \multicolumn{2}{c}{4} & \multicolumn{2}{c}{30} & \multicolumn{2}{c}{60} & \multicolumn{2}{c}{75} \\
& 4 hours & \multicolumn{2}{c}{1 day } & \multicolumn{2}{c}{2 days } & \multicolumn{2}{c}{3 days } \\
\hline Water regimes & Tição & Tatu & Tição & Tatu & Tição & Tatu & Tição & Tatu \\
\hline CC & $90.2 \mathrm{aA}$ & $86.1 \mathrm{aA}$ & $92.6 \mathrm{aA}$ & $88.6 \mathrm{aA}$ & $96.1 \mathrm{aA}$ & $95.6 \mathrm{aA}$ & 94.5 a A & $92.9 \mathrm{aA}$ \\
DM & $87.2 \mathrm{aA}$ & $87.9 \mathrm{aA}$ & $80.2 \mathrm{bA}$ & $86.1 \mathrm{aA}$ & $95.2 \mathrm{aA}$ & $95.1 \mathrm{aA}$ & 94.8 a A & $92.4 \mathrm{aA}$ \\
DS & $75.6 \mathrm{bA}$ & $81.9 \mathrm{aA}$ & $73.0 \mathrm{bA}$ & $71.4 \mathrm{bA}$ & $93.5 \mathrm{bA}$ & $91.8 \mathrm{bA}$ & 87.5 a B & $93.2 \mathrm{aA}$ \\
\hline C.V. (\%) & 6.76 & \multicolumn{2}{c}{5.80} & \multicolumn{2}{c}{1.27} & & 1.78
\end{tabular}

Means followed by the same letter, between the same DAT, upper case on the line and lower case in the column, do not differ by the Tukey test at the $5 \%$ probability. C.V. - Coefficient of variation. 
$\mathrm{CO}_{2}$ assimilation rate decreased at 15 DAT as the water volume supplied to the plants of both cultivars decreased (Table 3). In the other periods, the rates were similar, with changes being only observed in the cultivar IAC Tatu ST under SD water regime at 60 DAT. There was no difference between cultivars.

Stomatal conductance was significantly lower at 15 DAT in the two cultivars under MD and SD. In the other periods, except for cultivar IAC Tatu ST under SD water regime at $60 \mathrm{DAT}$, stomatal conductance values in the two water deficit conditions were similar to the control treatment (FC). There was no significant difference between cultivars (Table 3 ).

Transpiration decreased only at 15 DAT for both cultivars under MD and SD water regimes and with no difference between cultivars. In general, stomatal resistance was significantly higher under the SD water regime, with no differences between cultivars (Table 3).

Table 3 - $\mathrm{CO}_{2}$ assimilation rate, stomatal conductance, stomatal resistance, and transpiration on leaves of Arachis hypogaea (cv IAPAR 25 Tição (Tição) or cv IAC Tatu ST (Tatu)) in the conditions of field capacity (FC - without water deficit), moderate water deficit (MD - 50\% water deficit) and severe water deficit (SD - 75\% water deficit), at 15, 45 and 60 days after treatments starts (DAT).

\begin{tabular}{|c|c|c|c|c|c|c|}
\hline \multirow{3}{*}{ Water regimes } & \multicolumn{6}{|c|}{$\mathrm{CO}_{2}$ assimilation rate $\left(\mu \mathrm{mol} \mathrm{CO}_{2} \mathrm{~m}^{-2} \mathrm{~s}^{-1}\right)$} \\
\hline & \multicolumn{2}{|c|}{15 DAT } & \multicolumn{2}{|c|}{45 DAT } & \multicolumn{2}{|c|}{60 DAT } \\
\hline & Tição & Tatu & Tição & Tatu & Tição & Tatu \\
\hline FC & 30.79 aA & 28.69 aA & $23.60 \mathrm{aA}$ & $23.23 \mathrm{aA}$ & $19.04 \mathrm{aA}$ & $19.15 \mathrm{aA}$ \\
\hline MD & $13.36 \mathrm{bA}$ & $15.16 \mathrm{bA}$ & $23.98 \mathrm{aA}$ & $23.79 \mathrm{aA}$ & $19.36 \mathrm{aA}$ & $20.71 \mathrm{aA}$ \\
\hline SD & $5.28 \mathrm{cA}$ & $3.28 \mathrm{cA}$ & $17.27 \mathrm{aA}$ & $15.68 \mathrm{aA}$ & $16.06 \mathrm{aA}$ & $8.86 \mathrm{bA}$ \\
\hline C.V. (\%) & \multicolumn{2}{|c|}{26.07} & \multicolumn{2}{|c|}{25.10} & \multicolumn{2}{|c|}{29.76} \\
\hline \multirow{3}{*}{ Water regimes } & \multicolumn{6}{|c|}{ Stomatal conductance (mol m-2 s-1) } \\
\hline & \multicolumn{2}{|c|}{15 DAT } & \multicolumn{2}{|c|}{45 DAT } & \multicolumn{2}{|c|}{60 DAT } \\
\hline & Tição & Tatu & Tição & Tatu & Tição & Tatu \\
\hline FC & $0.88 \mathrm{aA}$ & $0.80 \mathrm{aA}$ & $1.29 \mathrm{aA}$ & $1.19 \mathrm{aA}$ & $1.21 \mathrm{aA}$ & $1.10 \mathrm{aA}$ \\
\hline MD & $0.38 \mathrm{bA}$ & $0.33 \mathrm{bA}$ & $1.28 \mathrm{aA}$ & $1.23 \mathrm{aA}$ & $1.24 \mathrm{aA}$ & $0.98 \mathrm{abA}$ \\
\hline SD & $0.20 \mathrm{bA}$ & $0.19 \mathrm{bA}$ & $0.96 \mathrm{aA}$ & $0.96 \mathrm{aA}$ & $0.65 \mathrm{bA}$ & $0.55 \mathrm{bA}$ \\
\hline C.V. (\%) & \multicolumn{2}{|c|}{24.06} & \multicolumn{2}{|c|}{23.87} & \multicolumn{2}{|c|}{22.61} \\
\hline \multirow{3}{*}{ Water regimes } & \multirow{2}{*}{\multicolumn{4}{|c|}{$\begin{array}{c}\text { Transpiration }\left(\mathrm{mmol} \mathrm{m}^{-2} \mathrm{~s}^{-1}\right) \\
45 \mathrm{DAT}\end{array}$}} & \multirow{2}{*}{\multicolumn{2}{|c|}{60 DAT }} \\
\hline & & & & & & \\
\hline & Tição & Tatu & Tição & Tatu & Tição & Tatu \\
\hline FC & $15.53 \mathrm{aA}$ & $16.07 \mathrm{aA}$ & $15.38 \mathrm{aA}$ & $16.05 \mathrm{aA}$ & $13.43 \mathrm{aA}$ & $12.97 \mathrm{aA}$ \\
\hline MD & $10.21 \mathrm{bA}$ & $10.69 \mathrm{bA}$ & $16.76 \mathrm{aA}$ & $16.35 \mathrm{aA}$ & $11.32 \mathrm{aA}$ & $12.42 \mathrm{aA}$ \\
\hline SD & $9.49 \mathrm{bA}$ & $7.44 \mathrm{cA}$ & $16.49 \mathrm{aA}$ & $16.36 \mathrm{aA}$ & $12.82 \mathrm{aA}$ & $12.21 \mathrm{aA}$ \\
\hline C.V. (\%) & \multicolumn{2}{|c|}{14.72} & \multicolumn{2}{|c|}{9.14} & \multicolumn{2}{|c|}{22.27} \\
\hline
\end{tabular}

Means followed by the same letter, upper case on the line and lower case in the column, do not differ by the Tukey test at the $5 \%$ probability. C.V. - Coefficient of variation.

Peanut plants grown under water deficit showed higher stomatal density, i.e., a greater number of stomata per area unit when compared to plants grown without deficit (Table 4). The greater the deficit, the greater the stomatal number observed in both cultivars. Plants of cultivar IAPAR 25 Tição under SD and MD had an increase of $26.5 \%$ and $15 \%$, respectively, in the stomatal number. For the IAC Tatu ST cultivar, stomatal number was $34.5 \%$ and $12.7 \%$ higher than FC under SD and MD, respectively. Comparing cultivars, cultivar IAPAR 25 Tição showed higher stomatal number per leaf area than cultivar IAC Tatu ST in all treatments, being $28 \%$ higher without water deficit, $31 \%$ higher under moderate water deficit, and $20 \%$ higher under severe water deficit. Both cultivars had their stomata reduced in length and width under severe water deficit (Table 4). IAPAR 25 Tição showed stomatal reduction of $8 \%$ in length and $6 \%$ in width, while IAC Tatu ST showed reductions of $12 \%$ and $11 \%$, respectively.

Plants that grew under SD showed higher proline contents compared to other water regimes. In relation to plants at $\mathrm{FC}$, those cultivated under SD showed proline content 4.25 -fold higher in leaflets and significant difference between plants at FC and under MD was not observed. There were also no significant differences between cultivars (Table 5).

Grain dry matter and number of grains significantly decreased as the water amount supplied to the plants reduced. Regarding grain dry matter, plants under SD of cultivar IAPAR 25 Tição and IAC Tatu ST produced approximately 9.6 and 5 -fold less, respectively, than plants at FC. Under MD, grain dry matter was reduced in approximately half compared to plants at FC in both cultivars. Regarding number of grains, it was observed that plants under SD and MD produced 3 and 1.4-fold less, respectively, than plants at FC in both cultivars. Comparing cultivars, difference was observed only for grain dry matter of plants grown at field capacity (without water deficit), with higher mean values for cultivar IAPAR 25 Tição, indicating this cultivar as more productive under adequate water conditions (Table 6). 
Table 4 - Number ( $n$ o $\mathrm{mm}^{-2}$ ) and size of stomata $(\mu \mathrm{m})$ of the abaxial face of leaves of Arachis hypogaea (cv IAPAR 25 Tição (Tição) and cv IAC Tatu ST(Tatu)) in the conditions of field capacity (FC - without water defcit), moderate water deficit (MD - 50\% water deficit) and severe water deficit (SD - 75\% water deficit).

\begin{tabular}{lcccccc}
\hline \multirow{2}{*}{ Water regimes } & \multicolumn{2}{c}{ Number of stomata } & \multicolumn{2}{c}{ Stomata length } & \multicolumn{2}{c}{ Stomata width } \\
& Tição & Tatu & Tição & Tatu & Tição & Tatu \\
\hline FC & $178.8 \mathrm{bA}$ & $139.7 \mathrm{bB}$ & $20.36 \mathrm{aA}$ & $20.61 \mathrm{aA}$ & $16.10 \mathrm{aA}$ & $15.77 \mathrm{aA}$ \\
MD & $205.6 \mathrm{abA}$ & $157.5 \mathrm{bB}$ & $20.42 \mathrm{aA}$ & $19.88 \mathrm{aA}$ & $15.25 \mathrm{bB}$ & $15.78 \mathrm{aA}$ \\
SD & $226.1 \mathrm{aA}$ & $187.9 \mathrm{aB}$ & $18.75 \mathrm{bA}$ & $18.21 \mathrm{bA}$ & $15.20 \mathrm{bA}$ & $14.05 \mathrm{bB}$ \\
\hline C.V. (\%) & \multicolumn{2}{c}{24.05} & \multicolumn{2}{c}{9.01} & \multicolumn{3}{c}{3.48} \\
\hline
\end{tabular}

Means followed by the same letter, upper case on the line and lower case in the column, do not differ by the Tukey test at the $5 \%$ probability. C.V. - Coefficient of variation.

Table 5 - Mean proline content in Arachis hypogaea leaflets (IAPAR 25 Tição or IAC Tatu ST) under conditions of field capacity (CC - without water deficit), moderate water deficit (DM - 50\% water deficit) and severe water deficit (DS - 75\% water déficit) at 75 DAT.

\begin{tabular}{lc}
\hline Water regimes & Proline $\left(\mu \mathrm{mol} \mathrm{g}{ }^{-2}\right.$ Fresh mass $)$ \\
\hline FC & $0.59 \mathrm{c}$ \\
MD & $1.66 \mathrm{~b}$ \\
SD & $3.10 \mathrm{a}$ \\
CV & $16.67^{*}$ \\
\hline Cultivars & Proline $(\mu \mathrm{mol} \mathrm{g} \text { Fresh mass })^{-2}$ \\
\hline IAPAR 25 Tição & $1.78 \mathrm{a}$ \\
IAC Tatu ST & $1.78 \mathrm{a}$ \\
CV & $16.67^{*}$ \\
\hline
\end{tabular}

Means followed by the same letter in the column did not present significant differences at $5 \%$ probability by the Tukey test. Transformed values: $y=\sqrt{1+x}$.

Table 6 - Mean values of grain dry mass $(\mathrm{g})$ and number of grains per plant produced by Arachis hypogaea (cv. IAPAR 25 Tição (Tição) and IAC Tatu ST (Tatu)) under field capacity (FC - without water déficit), moderate water deficit (MD $-50 \%$ water deficit), and severe water deficit (SD - 75\% water deficit) conditions at 80 DAT.

\begin{tabular}{lcccc}
\hline \multirow{2}{*}{ Water regimes } & \multicolumn{2}{c}{ Dry mass of grains per plant $(\mathrm{g})$} & \multicolumn{2}{c}{ Number of grains per plant } \\
& Tição & Tatu & Tição & Tatu \\
\hline FC & $31.97 \mathrm{aA}$ & $23.16 \mathrm{aB}$ & $38.87 \mathrm{aA}$ & $40.20 \mathrm{aA}$ \\
MD & $15.61 \mathrm{bA}$ & $12.93 \mathrm{bA}$ & $27.33 \mathrm{bA}$ & $28.80 \mathrm{bA}$ \\
SD & $3.33 \mathrm{cA}$ & $4.66 \mathrm{cA}$ & $12.33 \mathrm{cA}$ & $14.40 \mathrm{cA}$ \\
\hline C.V. (\%) & & 5.73 & & \multicolumn{3}{c}{18.30} \\
\hline
\end{tabular}

Means followed by the same letter, upper case on the line and lower case in the column, do not differ by the Tukey test at $5 \%$ probability level. C.V. - Coefficient of variation.

Shoot dry matter (SDM) decreased as water deficit increased. Plants under SD of cultivar IAPAR 25 Tição and IAC Tatu ST produced approximately 3 and 4-fold less SDM, respectively, than plants at FC. The SDM of plants under MD was approximately 1.5 -fold lower than that of plants at FC in both cultivars. Regarding root dry matter (RDM), decrease caused by water deficit was observed but without significant difference between deficits in both cultivars. Plants under SD and MD produced 3 and 1.4-fold less, respectively, than plants at FC in both cultivars.
Comparing cultivars, difference was observed only for the grain dry matter of plants grown at field capacity (without water deficit), with higher value for IAPAR 25 Tição. The root/shoot ratio was higher in plants under SD in both cultivars, with no difference between the two other water regimes. Comparing cultivars, difference was only observed for SDM at FC and under MD conditions, in which IAPAR 25 Tição produced $24 \%$ and $18 \%$ less than IAC Tatu ST at FC and under MD, respectively (Table 7). 
Table 7 - Average values for shoot dry mass (SDM) and root (RDM) dry mass (g), and ratio between SDM and RDM by Arachis hypogaea (cv IAPAR 25 Tição (Tição) and IAC Tatu ST (Tatu)) in the conditions of field capacity (FC - without water deficit), moderate water deficit (MD - 50\% water deficit) and severe water deficit (SD - 75\% water deficit), at 80 DAT.

\begin{tabular}{lccrrrr}
\hline \multirow{2}{*}{ Water regimes } & \multicolumn{2}{c}{ SDM $(\mathrm{g})$} & \multicolumn{2}{c}{ RDM $(\mathrm{g})$} & \multicolumn{2}{c}{ RDM/SDM } \\
& Tição & Tatu & \multicolumn{1}{c}{ Tição } & Tatu & Tição & Tatu \\
\hline FC & $47.42 \mathrm{aB}$ & $62.25 \mathrm{aA}$ & $11.73 \mathrm{aA}$ & $13.71 \mathrm{aA}$ & $0.25 \mathrm{bA}$ & $0.22 \mathrm{abA}$ \\
MD & $32.16 \mathrm{bB}$ & $39.02 \mathrm{bA}$ & $6.17 \mathrm{bA}$ & $6.90 \mathrm{bA}$ & $0.19 \mathrm{bA}$ & $0.18 \mathrm{bA}$ \\
SD & $16.59 \mathrm{cA}$ & $16.01 \mathrm{cA}$ & $6.06 \mathrm{bA}$ & $4.29 \mathrm{bA}$ & $0.37 \mathrm{aA}$ & $0.27 \mathrm{aA}$ \\
\hline C.V. (\%) & \multicolumn{2}{c}{2.03} & \multicolumn{2}{c}{34.88} & \multicolumn{2}{c}{3.80} \\
\hline
\end{tabular}

Means followed by the same letter, upper case on the line and lower case in the column, do not differ by the Tukey test at the $5 \%$ probabilityl. C.V. - Coefficient of variation.

\section{Discussion}

Significant differences were not observed for RWC between water regimes at 15 DAT possibly as the deepest roots could take advantage of the water offered at sowing. Over time (30 and 60 DAT), plants that received less water (SD) showed lower water content. At 75 DAT, at the end of the crop cycle, RWC showed no difference between water conditions as plants acclimatized to the lower water volume received. Superficial roots were sufficiently supplied even with the reduced water volume, maintaining leaf water content in plants that showed decreased shoot dry matter and transpiration in the leaf surface.

Decrease of photosynthesis, stomatal conductance, and transpiration occurred predominantly in the initial phase of water deficit. Decrease of photosynthetic capacity is an important response of the plant to water deficit. As the stomata controls $\mathrm{CO}_{2}$ and water vapor diffusion, its responses to water deficit are fundamental to control the efficiency of $\mathrm{CO}_{2}$ assimilation and water saving. However, over time, plants acclimated to the condition of decreased water availability and started to not show differences in these physiological variables. Taiz \& Zeiger (2013) stated that increasing stomatal resistance under water deficit conditions is important to regulate water loss by the plant and to control $\mathrm{CO}_{2}$ absorption rate. According to Larcher (2000), leaves grown under water deficit conditions can show modifying alterations, such as smaller stomata and in greater quantity. Thus, the resistance of the boundary layer is increased and the air around the stomata becomes more humid, decreasing water loss by transpiration. This statement corroborates the findings of the present study, in which peanut plants grown under water deficit had a greater stomatal number per area when compared to plants grown at FC.

Peanut plants accumulate proline as a mechanism associated with the ability to tolerate water deficit. Proline increase has also been observed in other studies with peanut subjected to water deficit (Alvarenga et al., 2011; Monteiro et al., 2014; Yamamoto et al., 2014; Araújo et al., 2017). Better tolerance to water deficit is attributed to proline increases in all these studies, being considered a biochemical and physiologi- cal indicator of effects of water stress.

Increases in proline contents in peanut cultivars subjected to water deficit were also observed by Nogueira et al. (1998). This amino acid, normally present in small amounts in plants, has its concentration increased under stress conditions to allow osmotic adjustment and stabilize membranes, preserving the integrity of compounds such as proteins and enzymes (Nogueira et al., 2001; Jaleel et al., 2007; Efeoğlu et al., 2008; Giannakoula et al., 2008).

Analyzing grain production, it is noted that both cultivars were extremely sensitive to water deficit, and the greater the water restriction, the greater the reduction. It is important to emphasize that the peanut limits its productive potential in pot conditions, underestimating field condition values. According to Boote et al. (1982), this oilseed seems to have the genetic ability to deepen its roots and extract water in higher depths. Therefore, to better evaluate this variable, it is recommended to conduct experiments under field conditions. Comparing the cultivars at adequate water supply conditions (FC), it is observed that the IAPAR 25 Tição showed higher grain dry matter due to the genetic traits of this cultivar.

Regarding shoot dry matter production, it is observed that this variable was also influenced proportionally to water reduction. Shoot reduction in plants is considered a defense mechanism against water deficiency, as with fewer leaves and branches, the total transpiration of the plant decreases in order to avoid permanent wilt. The result corroborates Araújo and Ferreira (1997), who observed significant decrease in the shoot dry matter of peanut plants subjected to water deficit at different stages of development. Correia \& Nogueira (2004) also observed that peanut plants subjected to water deficit decreased biomass allocation to the shoot and increased biomass allocation to the roots. Comparing cultivars, IAPAR 25 Tição showed decreased shoot dry matter at FC and under MD conditions, which was attributed to the genetic expression of the cultivar.

The results of root/shoot ratio showed that root dry matter was initially more affected than shoot dry matter under moderate deficit condition. However, under severe water deficit, shoot dry matter accumula- 
tion was more severely affected than root dry matter in both cultivars. As the root/shoot ratio increased when the water deficit changed from moderate to severe, photoassimilate allocation from the shoot to the root system also proportionally increased, increasing the root/shoot ratio because while the shoot showed significant and constant decrease of DM with increasing water deficit, difference was not observed in the root system.

\section{Conclusions}

In the initial period of water deficit, both cultivars developed physiological mechanisms of acclimatization to water deficit. Besides increasing proline production, decreases in the relative water content of leaves, $\mathrm{CO}_{2}$ assimilation rate, stomatal conductance, and transpiration were observed. Such physiological changes negatively affected grain dry matter accumulation and the number of grains, as well as dry matter accumulation in shoots and roots.

\section{Acknowledgement}

To the Agronomic Institute of Paraná for the structure provided for conduct experiments and analyzes.

\section{References}

Alvarenga ICA, Queiroz GA, Honório ICG, Valadares RV, Martins ER (2011) Prolina livre em alecrim-pimenta sob estresse hídrico antes da colheita. Revista Brasileira de Plantas Medicinais 13:539-541.

Araújo ED, Melo AS, Rocha MS, Carneiro RF, Rocha MM (2017) Genotypic variation on the antioxidative response of cowpea cultivar sexposed to osmotic stress. Revista Caatinga 30(4):928-937.

Araújo WF, Ferreira LGR (1997) Efeito do déficit hídrico durante diferentes estádios do amendoim. Pesquisa Agropecuária Brasileira 32(5):481-484.

Bates LS, Waldren RP, Teare ID (1973) Rapid determination of free proline for water stress studies. Plant and Soil 39:205-207.

Boote KJ, Stansell JR, Schubert AM, Stone JF (1982) Irrigation, water use and water relation. In: Patee $\mathrm{HE}$, Young CT (ed) Peanut science and technology, Texas: American Press. p.164-205.

Carvalho CJR (2005) Respostas de plantas de Schizolobium amazonicum [S. parahybavar. amazonicum] e Schizolobium parahyba [Schizolobium parahybum] à deficiência hídrica. Revista Árvore 29(6):907-914.

Cato SC, Albert LHB, Monteiro ACBA (2008) Amendoinzeiro. In: CASTRO PRC. Manual de Fisiologia Vegetal: Fisiologia de Cultivos. Piracicaba: Editora Ceres. p.26-35.
Correia KG, Nogueira RJMC (2004) Avaliação do crescimento do amendoim (Arachis hypogaea L.) submetido a déficit hídrico. Revista de Biologia e Ciência da Terra 4(2).

Efeoğlu B, Ekmekçi Y, Çiçek N (2008) Physiological responses of three maize cultivars to drought stress and recovery. South African Journal of Botany 75:34-42.

Farooq M, Wahid A, Kobayashi N, Fujita D, Basra SMA (2009) Plant drought Stress: Effects, mechanisms and management. Agronomy for Sustainable and Development 29(01):185-212.

Ferrari Neto J, Da Costa CHM, Castro GSA (2012) Ecofisiologia do amendoim. Scientia Agraria Paranaensis 11 (4):1-13.

Giannakoula A, Moustakas M, Mylona P, Papadakis I, Yupsanis T (2008) Aluminum tolerance in maize is correlated with increased levels of mineral nutrients, carbohydrates and proline, and decreased levels of lipidperoxidation and al accumulation. Journal of Plant Physiology 165 (4):385-396.

Jaleel CA, Manivannan P, Kishorekumar A, Sankar B, Gopi R, Somasundaram R, Paneerselvam R (2007) Alterations in osmoregulation, antioxidant enzymes and indole alkaloid levels in Catharanthus reseus exposed to water deficit. Colloids and Surfaces B: Biointerfaces 59(2):150-157.

Kraus JE, Arduin M (1997) Manual básico de métodos em morfologia vegetal. Editora da Universidade Rural do Rio de Janeiro. 198p.

Larcher W (2000) Ecofisiologia vegetal. São Carlos: RIMA. 531p.

Monteiro J.G, Cruz FJR, Nardin MB, Santos DMM (2014) Crescimento e conteúdo de prolina em plântulas de guandu submetidas a estresse osmótico e à putrescina exógena. Pesquisa Agropecuária Brasileira 49(1):18-25.

Nascimento SP, Bastos EA, Araújo ECE, Freire Filho FR, Da Silva EM (2011) Tolerância ao déficit hídrico em genótipos de feijão-caupi. Revista Brasileira de Engenharia Agrícola e Ambiental 15(8):853-860.

Nogueira RJMC, Moraes JAP, Burity HA, Bezerra Neto $E$ (2001) Alterações na resistência à difusão de vapor das folhas e relações hídricas em aceroleiras submetidas a déficit de água. Revista Brasileira de Fisiologia Vegetal 13(1)75-87.

Nogueira RJMC, Santos CRd, Neto EB, Santos VFD (1998) Comportamento fisiológico de duas cultivares de amendoim a diferentes regimes hídricos. Pesquisa Agropecuária Brasileira 33:1963-1969. 
Nogueira RJMC, Santos, RCD (2000) Alterações fisiológicas no amendoim submetido ao estresse hídrico. Revista Brasileira de Engenharia Agrícola e Ambiental 4(1):41-45.

Pereira JWL, Melo Filho PA, Albuquerque MB, Nogueira RJMC, Santos RC (2012) Mudanças bioquímicas em genótipos de amendoim submetidos a déficit hídrico moderado. Revista Ciência Agronômica 43(4):766-773.

Santos HG, Jacomine PKT, Anjos LHC, Oliveira VA, Lumbreras JF, Coelho MR, Almeida JA, Cunha TJF, Oliveira JB (2013) Sistema Brasileiro de Classificação de Solos. 3 ed. Brasília: Embrapa. 353 p.
Taiz L, Zeiger E (2013) Fisiologia Vegetal. 5 ed. Porto Alegre: Artmed. 954p.

Vorassot N, Songsri P, Akkasaeng C, Jogloy S, Patanothais A (2003) Efeito of water stress on yield and agronomic characters of peanut. Songklanakarin Journal of Science Technology 25:283-288.

Yamamoto CJT, Minamiguchi JY, Braga I, Machado Neto NB, Custódio CC (2014) Water-deficit tolerance induction during germination of Jalo Precoce bean (Phaseolus vulgaris L.) cultivar. Acta Physiologie e Plantarum 36(11):2897-2904. 